\title{
Analysing the Effects of an 8-Week Exercise Program Applied to Sedentary Individuals on Body Composition, Self-Confidence and Social-Physical Anxiety Levels
}

\author{
Selin Baikoğlu ${ }^{1}$, Suzan Dal ${ }^{2}$, Burcu Güvendi ${ }^{3}$, Cemile Nihal Yurtseven ${ }^{4}$, Uğur Gençtürk ${ }^{5}$ \\ ${ }^{1}$ Istanbul University -Cerrahpaşa Sport Sciences Faculty, Sport and Health Department, Istanbul, Turkey \\ ${ }^{2}$ Istanbul University, The School of Foreign Languages, Istanbul, Turkey \\ ${ }^{3}$ Istanbul University-Cerrahpasa Sport Sciences Faculty, Physical Education and Sports Teaching Department, Istanbul, \\ Turkey \\ ${ }^{4}$ Istanbul University-Cerrahpaşa Sport Management Sciences Department, Istanbul, Turkey \\ ${ }^{5}$ WFT Personal Coaching, 34335 Besiktas-Istanbul, Turkey \\ Correspondence: Selin Baikoğlu, Istanbul University -Cerrahpaşa Sport Sciences Faculty, Sport and Health Department, \\ Istanbul, Turkey.
}

Received: May 10, 2019

Accepted: June 16, 2019

Online Published: June 26, 2019

doi:10.11114/jets.v7i8.4264

URL: https://doi.org/10.11114/jets.v7i8.4264

\begin{abstract}
It is believed that while sports turns individuals into physiologically healthier individuals, it also has psychologically positive effects on individuals. This study is conducted to analyse the effects of an 8-week exercise program applied to sedentary individuals on self-confidence and their social-physical anxiety level by analysing the impacts on body composition. The experiment group of this study is limited to a total of 40 individuals, 20 female and 20 male, who are members of a private fitness club and who did not do sports regularly. After all the details of the study are explained to the experiment group and consent is taken, a self-confidence scale and social physical anxiety scale are applied before and after an 8-week training program. The exercise program was applied for 8 weeks and 3 days per week at the same hour.The8-week exercise program applied to the 40 fitness club members resulted in positive increases in kilogram, fat percentage and fat mass values of the participants. It is found that positively developed physical changes decreased the social-physical anxiety level of participants and increased self-confidence levels. Additionally, a negative and medium level relationship is determined between the social-physical anxiety level and the self-confidence level $(\mathrm{p}<0.05)$.The physical activities during 8 weeks resulted in positive changes in participants' appearances. Additionally, it is found that regular physical activity decreases the social physical anxiety levels of individuals and increases self-confidence with changes in physical appearance.
\end{abstract}

Keywords: sport, physical change, physical anxiety, self-confidence

\section{Introduction}

Physically and psychologically healthy individuals and societies are becoming harder to find these days because technological developments have led humans to laziness. As machines are introduced into our daily lives, home-appliances that facilitate housework have increased, and the number of vehicles have increased therefore physical activity as well as energy consumption have been minimised. Sedentary individuals create a physically weak and unhappy society with a low labour force. Therefore, the number of healthy individuals and physical compliance should be at the highest level for a healthy society (Türk, 2016). Especially, as age increases, energy need decreases due to lower physical activity (Peker et al., 200). In order to take precautions against bodily and physical problems due to a sedentary lifestyle, one should increase physiological capacity and sustain physical compliance and health for many years, which requires regular exercise and physical activity as its most basic element (Zorba, 2001). Social-physical anxiety, which is one of the concepts related with anxiety of individuals due to appearance, is defined as anxiety and stress felt by individuals when physical appearance of these individuals are evaluated by other people (Hart et al., 1989).

Social-physical anxiety emerges in individuals who desire an ideal physical appearance (Davison and Mccabe, 2005). On 
the other hand, self-confidence is feeling positive towards one's self (Weinberg and Gould, 2003).Because of the positive feelings, individuals are at peace with himself/herself and the people around them (Sarıçam, 2012). The first condition to love anything else is self-love. The concepts of self-love and self-confidence are synonymous; and trust, love, creativity and self-expression properties are the reflections of self-confidence (Şahin et al., 2012). Since individuals with high self-confidence have properties such as controlled emotions and behaviours, these individuals can have leading roles in social life. In this sense, sport and physical activities have great contribution to developing both the physiologic and psychological health of individuals (Zorba et al., 2000). Additionally, advanced technology causes individuals to live in a more passive routine and turns them into sedentary beings. Sedentary lifestyle is the direct or indirect cause of various diseases such as cardiovascular diseases, stress, joint deformations, high blood pressure, obesity, spine diseases, and psychological depression (Altintaş and Aşç1, 2005). In addition to physical activity, a healthy diet is of importance in terms of physical compliance and appearance (Paoli and Bianco, 2015). Life style also plays a role in individuals' physical compliance, and regular physical activity ensures the permanency of it (Paoliet al., 2015). Accordingly, when literature was reviewed, it was found that Suzuki et al. (1998) applied an exercise program with cycling ergometer of $40 \%$ intensity of maximal oxygen consumption during 12 weeks, 5 days per week on young females and found that there was significant decrease in body mass index, fat index, body mass and skin fold thicknesses. Özdemir, Çuğ and Çelik (2010) expanded the scope of the study and analysed the effects of the exercise program on the social-physical anxiety level of university students and found that social-physical anxiety level of both control and aerobic group individuals that attended 10-week swiss ball exercises significantly decreased (Özdemir et al., 2010).

This study is conducted to analyse the effects of a 8 -week exercise program applied to sedentary individuals on self-confidence and social physical anxiety level by analysing the impacts on body composition. Additionally, the self-confidence levels of the participants relative to the intensity of the exercise program are analysed.

\section{Materials and Methods}

\subsection{Participants}

A total of 40 individuals were selected, of which 20 were female and 20 were male. The participants were the members of the WTF Personal Coaching in Akatlar, İstanbul with an age average of 31.98( \pm 8.2$)$. Participants were sedentary healthy individuals who desired to start regular exercise to increase their general health level and keep form. Before the 8-week exercise program, participants were asked to take a sports report from a doctor to determine whether their health status are suitable for sports. This study was conducted on individuals who could do sports. Participants were informed about the process before this study.

\subsection{Data Collection Tools}

\subsubsection{Self-Confidence Scale}

One of the data collection tools of this study is the self-confidence scale that was developed by Akın (Akın, 2007). The scale items consisted of 5-point Likert (1:never - 5:always) type items. For total scores of self-confidence scale, 2.5 point indicated low self-confidence, 2.5-3.5 indicated moderate self-confidence and 3.5 or higher indicated high self-confidence.

\subsubsection{Social Physical Anxiety Inventory}

The social-physical anxiety scale developed by Hart et al. (1989) was adopted as a second data collection tool. This inventory consists of 12 items and each item is scored with a 5-point scale. Scores from this inventory changes between 12-60 points. A reliability and validity study of this inventory on the Turkish population was conducted by Ball et al.

\subsubsection{Application Method}

The exercise program applied under this study was conducted for total of 8 weeks and 3 days per week. Each training was applied as a 45-minute exercise program after 10 minutes of warming-up. By considering the individual differences of the participants, training programs with different content (exercise type, number, set and repetition, weekly application) and intensity were prepared based on the physical fitness of the individuals. Training sections consisted of cardiovascular exercise, exercise with sport equipment and flexibility exercise. Participants were asked to avoid different exercise other than those in the training program and to follow the program.

\subsubsection{Application of Exercise with Sport Equipment}

Before exercise, the participants were warmed up with a 10-minute low intensity aerobic exercise. After the warming sections and stretching, the weight exercise was applied. During the weight exercise, participants were informed about correct breathing and adjusting movement speeds. For adaptation, 1 set was applied in the first training of first week. 2 sets were applied on the second training and complete sets were applied after the third training. Participants were given a functional exercise program that effected multiple muscle groups. For movements with weight, Brzycki 1RM Maximal 
Power Test was applied and the predicted weight intensity was determined. For each movement that contains a proximal muscle group, 3 sets were applied with a repetition of 15 and for distal muscle group, 2 sets were applied with a repetition of 15 with $65 \%$ of maximal weight. Participants rested for 1 minute between the sets and the weight was increased in the following trainings. While applying the selected weight exercise, the movement tempo was kept at 2:1:1 and 45 seconds between the set breaks and 75 seconds was given for the exercise transitions.

\subsection{Application of Cardiovascular Exercise}

\subsubsection{Application of Flexibility Training}

Stretching-extension exercises were applied by static stretching method for 15 seconds at the beginning and the end of the general program.

\subsubsection{Data Collection}

The scales adopted in this study were applied before and after the 8-week exercise program. The scales were completed approximately in 3 minutes by each member. Additionally, the height-body mass, body mass index (BMI), muscle-kg, fat-kg and body composition measurement values were recorded before and after the application. Bioimpedance measurement lasted approximately for 1 minute.

\subsubsection{Statistical Analysis}

For data analysis, the SPSS 21 package program was adopted. Frequency analysis was conducted for the measurements regarding demographic features and two-related samples test was applied to identify the differences between the pre-test and post-test measurements. Additionally, a correlation analysis was applied to measure the relationship between self-confidence and social physical anxiety.

\section{Results}

Table 1. Statistics for the physical pre-test/post-test scores of participants of training program

\begin{tabular}{|c|c|c|c|c|c|c|}
\hline \multirow{3}{*}{$\begin{array}{l}\mathrm{N}=40) \\
\text { Tests }\end{array}$} & \multicolumn{2}{|c|}{ Pre-training } & \multicolumn{4}{|c|}{ Post-training } \\
\hline & \multicolumn{2}{|c|}{ Mean } & \multicolumn{2}{|c|}{ Mean } & \multirow[t]{2}{*}{$\mathrm{Z}$} & \multirow[t]{2}{*}{$\mathrm{P}$} \\
\hline & SD & & SD & & & \\
\hline Kilogram & 73.2 & 15.2 & 71.3 & 14.3 & -5.21 & .000 \\
\hline BMI & 24.5 & 4.19 & 23.9 & 3.86 & -5.35 & .000 \\
\hline Muscle-kg & 29.8 & 6.45 & 29.6 & 6.60 & -.658 & .511 \\
\hline Fat $\%$ & 26.5 & 8.81 & 25.0 & 8.12 & -5.21 & .000 \\
\hline Fat-Kg & 19.6 & 9.51 & 17.8 & 8.26 & -5.53 & .000 \\
\hline
\end{tabular}

Based on Table 1, there was a statistically significant difference between pre-test and post-test scores of the participants in terms of kilogram, BMI, fat percentage, fat $\mathrm{kg}(\mathrm{p}<0.05)$. There was no significant difference in the muscle- $\mathrm{kg}$ measurements.

Table 2. Statistics for self-confidence and social-physical anxiety pre-test/post-test scores of participants of the training program

\begin{tabular}{lllllll}
\hline $\mathbf{( N = 4 0 )}$ Tests & \multicolumn{2}{l}{ Pre-training } & \multicolumn{2}{l}{ Post-training } \\
\hline & \multicolumn{7}{c}{ Mean } & Mean & Z & P \\
& SD & \multicolumn{7}{c}{ SD } & & & \\
\hline Self-confidence & 3.93 & .46 & 4.13 & .35 & -4.37 & .000 \\
Social Physical & 34.61 & 6.78 & 32.34 & 6.55 & -6.25 & .000 \\
Anxiety & & & & & & \\
\hline
\end{tabular}

Based on Table 2, there was statistically significant difference between the pre-test and post-test scores of the participants in terms of self-confidence and social-physical anxiety $(\mathrm{p}<0.05)$. While the self-confidence scores increased after training, the social-physical anxiety scores decreased. 
Table 3. Correlation analysis between self-confidence and social physical anxiety

\begin{tabular}{llll}
\hline & & \multicolumn{1}{c}{$\begin{array}{l}\text { Social-Physical } \\
\text { Anxiety }\end{array}$} & Self-confidence \\
\hline \multirow{2}{*}{ Social-Physical Anxiety } & $\mathrm{R}$ & 1 & -.390 \\
\cline { 2 - 4 } & $\mathrm{p}$ & 40 & .41 \\
\cline { 2 - 4 } Self-confidence & $\mathrm{N}$ & $-.390 *$ & 40 \\
\cline { 2 - 4 } & $\mathrm{R}$ & .41 & 1 \\
\cline { 2 - 4 } & $\mathrm{p}$ & 40 & 40
\end{tabular}

Based on the correlation analysis in Table 3, a medium level $r=-390$ and negative relationship was determined between the self-confidence total values and the social-physical anxiety of participants $(\mathrm{p}<0.05)$.

\section{Discussion and Conclusion}

This study was conducted to analyse the effects of an 8-week exercise program applied to sedentary individuals on their self-confidence and social-physical anxiety level by analysing its impacts on body composition. Additionally, the self-confidence levels of the participants relative to the intensity of the exercise program are analysed.

There was significant difference in the pre-test and post-values of the participants in terms of kilogram, BMI, fat percentage and body mass index. Muscle-kg parameter showed no statistically significant result. Accordingly, it can be stated that the 8-week exercise program has a positive effect on the body composition values of sedentary individuals. Findings that support the results of this study can be given as follows. Baştuğ, Akandere and Yıldız (2011) found that a 8-week aerobic exercise has significantly decreased body mass and body mass index values of sedentary females and it was determined that body composition and the self-physical description of sedentary females are positively affected after a 8-week aerobic exercise program. In another study conducted with overweight sedentary females were seen to lose weight following a 12-week exercise program. Amano, Kanda and Maritani (2011) applied aerobic exercise to 18 obese participants for 3 months and 3 days per week and 30 minutes per day and found that there was a significant decrease in body mass, body mass index, body fat percentage, body fat mass and fatless body mass averages. Dalleck et al. (2009) applied a 12-week medium intensity aerobic exercise and walking program and found that there was a significant improvement in the physical values of participants.

When the self-confidence average values of sedentary individuals before and after training were considered, this value positively increased, and the social physical anxiety levels significantly decreased. Accordingly, it was seen that participants developed positive emotions due to positive improvement in their body compositions and increased their self-belief. Additionally, it can be said that their anxiety level decreased as a result of the desired physical changes that occurred in their physical appearance. The literature review showed that Özbek, Yoncalık and Alincak (2017) found a lower internal and external self-confidence level for sedentary students compared to athletic students. Alemdağ and Öncü (2015) determined that as participation in physical activity increased for students, their social appearance anxiety decreased. In a study by Zorba et al. (2012), regular exercise was found to facilitate the development of self-respect and increasing self-confidence. Also, recent research by Özbek (2017) emphasized that the participants' self-confidence was positively correlated with their exercise performance, and that as the performance increased, their sense of self-confidence improved.

Considering the findings in the literature, it can be stated that exercise has a positive effect on self-confidence and social-physical anxiety levels.

Findings of this study showed a negative relationship between social-physical anxiety and self-confidence. Accordingly, it can be said that as social physical anxiety decreased, the self-confidence and positive emotions of individuals increased. Krane et al. (2001) showed that as the satisfaction of individuals with their bodies increased, anxiety towards physical appearance decreased and as their contentment with body appearance decreased, their anxiety towards physical appearance increased.

Considering the 8-week regular exercise program for sedentary individuals in this research, and the related findings in literature, the current study has observed that since sportive activities require individuals to do regular exercise, to possess technique and competitiveness, their self-confidence improves and their social and physical anxieties decrease.

This study has certain limitations in terms of all findings and results. The most important limitation is the lack of tracking the eating habits of the participants during the exercise program. 
As a result, with regular exercise programs, it is seen that there is positive improvement in body composition (kilogram, BMI, fat percentage and fat-kg) of individuals, which decreases social-physical anxiety and increases self-confidence level of individuals. As individuals achieve an active life in which they can increase their expenditure of bodily energy and have a healthier life style instead of a sedentary life imposed by technology, it can be stated that these individuals develop a positive perception about themselves in psychological terms. Future studies may track the eating habits of participants by dieticians in addition to the exercise program which would clarify the results of this study.

\section{References}

Akın, A. (2007). Öz-Güven Ölçeği'nin Geliştirilmesi ve Psikometrik Özellikleri. Abant İzzet Baysal Üniversitesi Eğitim Fakültesi Dergisi, 7(2), 167-176.

Alemdag, S., \& Öncü, E. (2015). Öğretmen Adaylarının Fiziksel Aktiviteye Katılım ve Sosyal Görünüş Kaygılarının Incelenmesi. International Journal of Science Culture and Sport, 3(Special Issue 3), 288-300. https://doi.org/10.14486/IJSCS291

Altıntaş, A., \& Aşçı F.H. (2005). Fitness Uzmanlarının Bedenlerine Yönelik Algıları. Spormetre Beden Eğitimi ve Spor Bilimleri Dergisi, 3(3), 101-104. https://doi.org/10.1501/Sporm_0000000051

Amano, M., Kanda, T., \& Maritani, T. (2001). Exercise Training and Autonomic Nervous System Activity in Obese individuals. Medicine Science in Sports Exercise, 33(8), 1287-1291. https://doi.org/10.1097/00005768-200108000-00007

Ballı, Ö. M., Kirazcı, S., \& Aşçı, F. H. (2006). Sporcu ve Sporcu Olmayan Bayanların Sosyal Fizik Kaygı ve Beden imgesinden Hoşnut Olma Düzeyleri. Gazi Beden Eğitimi ve Spor Bilimleri Dergisi, 11(1), 9-16.

Baştug, G., Akandere, M., \& Yıldız, H. (2011). Sedanter Genç Bayanlarda Aerobik Egzersizin Vücut Kompozisyonu ve Kendini Fiziksel Tanımlama Değerlerine Etkisi. Spor ve Performans Araştırmaları Dergisi; 2(2), 22-27.

Bianco, A., Bellafiore, M., Battaglia, G., Paoli, A., Caramazza, G., Farina, F., \& Palma, A. (2010). The Effects of Indoor Cycling Training in Sedentary Overweight Women. Journal of Sports Medicine and Physical Fitness, 50(2), 159-165.

Dalleck, L. C., Allen, B. A., Hanson, B. A., Borresen, E. C., Erickson, M. E. \& De Lap, S. L. (2009). Dose-Response Relationship Between Moderate-Intensity Exercise Duration and Coronary Heart Disease Risk Factors in Postmenopausal Women. Journal Of Women's Health, 18(1), 105-113. https://doi.org/10.1089/jwh.2008.0790

Davison, T. E., \& McCabe, M. P. (2005). Relationships Between Men's and Women's Body İmage and Their Psychological, Social, and Sexual Functioning. Sex roles, 52(7-8), 463-475. https://doi.org/10.1007/s11199-005-3712-z

Hart, E. A., Leary, M. R., \& Rejeski, W. J. (1989). Tie Measurement of Social Physique Anxiety. Journal of Sport and exercise Psychology, 11(1), 94-104. https://doi.org/10.1123/jsep.11.1.94

Krane, V., Stiles-Shipley, J. A., Waldron, J., \& Michalenok, J. (2001). Relationships Among Body Satisfaction, Social Physique Anxiety, and Eating Behaviors in Female Athletes and Exercisers. Journal of sport behavior, 24(3).

Özbek, S., Yoncalık, M. T., \& Alıncak, F. (2017). Sporcu ve Sedanter Lise Öğrencilerinin Özgüven Düzeylerinin Karşlaştırılması (Kırşehir İli Örneği). Gaziantep Üniversitesi Spor Bilimleri Dergisi, 2(3), 46-56.

Özdemir, R. A., Mutlu, C. U. Ğ., \& Çelik, Ö. (2010). Genç Yetişkin Üniversite Öğrencilerinde Farklı Türde Egzersiz Uygulamalarının Sosyal Fizik Kaygı Düzeyine Etkisi. Hacettepe Journal Of Sport Sciences, 21(2), 60-70.

Paoli, A., \& Bianco, A. (2015). What is Fitness Training? Definitions and implications: A Systematic Review Article. Iran J Public Health, 44(5), 602-614.

Paoli, A., Moro, T., \& Bianco, A. (2015). Lift Weights to Fight Overweight. Clinical Physiology and Functional Imaging, 35(1), 1-6. https://doi.org/10.1111/cpf.12136

Peker, İ., Çiloğlu, F., \& Buruk, Ş. (2000). Egzersiz ve Egzersiz+ Diyetin Kan Lipidleri Üzerine Etkisi. Spor Araştırmaları Dergisi, 4(2), 33-46.

Sahin, M., Yetim, A. A., \& Çelik, A. (2012). Psikolojik Sağlamlığın Gelişiminde Koruyucu Bir Faktör Olarak Spor ve Fiziksel Aktivite. The Journal of Academic Social Science Studies, 5(8), 373-380.

Sarıçam, H., \& Güven, M. (2012). Özgüven ve Dini Tutum. The Journal of Academic Social Science Studies, International Journal of Social Science, 5(7), 573-586. https://doi.org/10.9761/jasss_244

Suzuki, S., Urata, G., Ishida, Y., Kanahisa, H., \& Yamamura, M. (1998). Influences of Low Intensity Exercise On Body Composition, Food Intake and Aerobic Power of Sedentary Young Emales, Appl.Human Sci; 17, 259-266. 
https://doi.org/10.2114/jpa.17.259

Türk, N. (2016). Sedanter Bayanlarda Uygulanacak Olan 3 Aylık Düzenli Bosu Egzersizin Fiziksel Uygunluk Seviyelerindeki Değişimin Vücut Imajı, Benlik Tasarımı ve Stres Düzeyine Etkisi (Master's thesis, Hitit Üniversitesi Sosyal Bilimler Enstitüsü).

Weinberg, R. S., Gould, D., \& Weinberg, R. (2003). Foundations of Sport and Exercise Psychology.

Zorba, E. (2001). Fiziksel Uygunluk (2. Bask1). Ankara: Gazi Kitabevi.

Zorba, E. (2012). Herkes İçin Yaşam Boyu Spor. Ankara: Nehir Yayınları.

Zorba, E., Yıldırım, S., Saygın, Ö., Yaman, R., \& Yıldırım, K. (2000). Orta Yaşlı Sedanter Bayanlarda Step Çalışmasının Bazı Fizyolojik, Motorik ve Yapısal Değerlere Etkisi. 1. Gazi Beden Eğitimi ve Spor Bilimleri Kongresi, 26-27.

\section{Copyrights}

Copyright for this article is retained by the author(s), with first publication rights granted to the journal.

This is an open-access article distributed under the terms and conditions of the Creative Commons Attribution license which permits unrestricted use, distribution, and reproduction in any medium, provided the original work is properly cited. 